\title{
Effect of dung deposition on small-scale patch structure and seasonal vegetation dynamics in mountain pastures
}

\author{
François Gillet $^{\mathrm{a}, \mathrm{b}, \mathrm{c}, *}$, Florian Kohler ${ }^{\mathrm{b}, \mathrm{c}}$, Charlotte Vandenberghe ${ }^{\mathrm{b}}$, Alexandre Buttler ${ }^{\mathrm{a}, \mathrm{b}}$ \\ ${ }^{a}$ Ecole Polytechnique Fédérale de Lausanne EPFL, Ecological Systems Laboratory ECOS, Station 2, 1015 Lausanne, Switzerland \\ ${ }^{\mathrm{b}}$ Swiss Federal Research Institute WSL, Station 2, 1015 Lausanne, Switzerland \\ ${ }^{\mathrm{c}}$ University of Neuchâtel, Soil and Vegetation Laboratory, Rue Emile-Argand 11, 2007 Neuchâtel, Switzerland
}

\section{A R T I C L E I N F O}

\section{Article history:}

Received 8 January 2009

Received in revised form 2 August 2009

Accepted 11 August 2009

Available online 3 September 2009

\section{Keywords:}

Cattle activity

Seasonal change

Spatial pattern

Micro-succession

\begin{abstract}
A B S T R A C T
Cattle activity greatly influences plant species composition and biomass production of grassland ecosystems. Dung deposition by cattle together with grazing and trampling can be considered as one of the important factors driving vegetation dynamics in pastures. The objective of this study was to investigate at $10-\mathrm{cm}$ and 1 -month resolution the plant community dynamics induced by dung deposition in two plant communities (a mesotrophic and an oligotrophic grassland) in a pasture of the Swiss Jura Mountains. Vegetation was sampled four or three times during the vegetation period in contiguous $10 \mathrm{~cm} \times 10 \mathrm{~cm}$ quadrats from the centre of the dung pat to a distance of $60 \mathrm{~cm}$. A lower grazing intensity near the dung pat was recorded for all observation periods. In the mesotrophic grassland the canopy was higher near the dung pat already one week after dung deposition. Vegetation around dung pats was submitted to two opposite fertilizing and grazing gradients, which induced changes in vegetation texture and structure at fine scale and short term. We observed a positive rank correlation between species turnover and distance to the dung for both communities, suggesting a seasonal stabilizing effect of dung on the plant composition of their direct surroundings $(0-10 \mathrm{~cm})$ likely due to cattle avoidance. Since dung pats are dropped every year in different locations, they create in the pasture a shifting mosaic of nutrient availability and grazing intensity inducing at seasonal scale microsuccessions in plant communities.
\end{abstract}

(c) 2009 Elsevier B.V. All rights reserved.

\section{Introduction}

Cattle activity greatly influences plant species composition and biomass production of grassland ecosystems (Olff and Ritchie, 1998; Olff et al., 1999; Bakker et al., 2004; Guretzky et al., 2007). Together with grazing and trampling, dung deposition by cattle can be considered as one of the most important factors explaining vegetation structure in pastures (Kohler et al., 2004a). Following a hierarchical approach of vegetation dynamics in pastures (Gillet, 2008), the effect of dung deposition can be observed or modelled at different spatial and temporal scales (Buttler et al., 2008). At large scale (100-1000 m), dung density differs among paddocks due to differences in stocking rate and range management. At medium scale $(10-100 \mathrm{~m})$, the spatial patterning of dung pat density is generally heterogeneous inside a paddock, especially for a large

\footnotetext{
* Corresponding author. Present address: Université de Franche-Comté, CNRS, UMR 6249 Chrono-environnement, 16 Route de Gray, 25030 Besançon Cedex, France.

E-mail address: francois.gillet@univ-fcomte.fr (F. Gillet).
}

paddock with various habitats and low stocking rate (White et al., 2001; Jewell et al., 2005; Kohler et al., 2006). In case this spatial pattern persists over years, it can lead to a redistribution of nutrients over the paddock, which in turn can induce a directional drift in plant succession (Jewell et al., 2007). At fine scale (0.1$10 \mathrm{~m}$ ) and short term (one season) the patchiness of dung deposition has a direct impact on local vegetation dynamics by altering biotic interactions and nutrient availability. This smallscale seasonal effect of dung deposition on vegetation structure and dynamics in grazed pastures has been poorly studied and is the subject of the present paper.

Each cow (adult bovine unit) produces about 10-15 dung pats per day, each covering an area of approximately $0.05 \mathrm{~m}^{2}$ (Marsh and Campling, 1970; MacDiarmid and Watkin, 1972). A fresh pat contains high nutrient contents, such as $1040 \mathrm{~kg} \mathrm{~N} \mathrm{ha}^{-1}$, $400 \mathrm{~kg} \mathrm{Kha}^{-1}, 280 \mathrm{~kg} \mathrm{Pha}^{-1}$ and $100 \mathrm{~kg} \mathrm{Sha}^{-1}$ (Haynes and Williams, 1993). A cattle dung pat is completely decomposed in a time span from a few weeks to several years, depending on water content, climatic conditions, season and activity of the soil fauna (Marsh and Campling, 1970; Dickinson and Craig, 1990). Dung deposition has an important effect on the chemical status of the 
soil. Although a significant proportion of the dung $\mathrm{N}$ is lost by $\mathrm{NH}_{3}$ volatilization (MacDiarmid and Watkin, 1972), dung deposition represents a potential source of available nutrients for plants (Shepherd et al., 2000; Aarons et al., 2004). A higher concentration of available soil $\mathrm{N}$ and $\mathrm{P}$ and exchangeable $\mathrm{K}$ was detected up to $15 \mathrm{~cm}$ around the dung pats (MacDiarmid and Watkin, 1972; Deenen and Middelkoop, 1992). Twelve months after dung application, Williams and Haynes (1995) observed that soil organic $\mathrm{C}$, nitrate and phosphate were still higher under dung pats than in control plots. Some residual effect on organic $C$ was still evident three years after cattle dung deposition.

Dung deposition has also an impact on the grazing behaviour by creating avoidance areas around deposited dung pats. Cattle tend to avoid grazing in the immediate vicinity of dung pats, in a way that a fringe of $10-20 \mathrm{~cm}$ of tall herbage surrounds rapidly the fresh dung pats and this exclusion effect persists until the pat has largely disappeared (Edwards and Hollis, 1982). Weeda (1967) found that herbage at the dung pat was usually $3-5 \mathrm{~cm}$ higher than herbage of the surrounding pasture. Large domestic and wild herbivores avoid the intake of food contaminated with faeces (Moe and Wegge, 2008), but animals may also graze preferentially on areas previously fertilised with urine (Jaramillo and Detling, 1992; Steinauer and Collins, 2001). Animal response to dung-affected pasture has been explained in terms of a trade-off between food intake and risk of parasite infection (Hutchings et al., 1999). The avoidance effect might be compensated through space and time scales, so that small-scale events have the potential to impact large-scale patch structure (Steinauer and Collins, 2001).

The combined effect of dung deposition, grazing avoidance and nutrient enrichment will have a direct effect on fine-scale vegetation structure and dynamics. Initially dung deposition is detrimental to herbage growth, because of smothering. The affected above-ground parts of most plants die most likely from a lack of light, being covered for several weeks by the dung pat (Williams and Haynes, 1995). This initial smothering is compensated by an increased plant growth around the dung pat till $40 \mathrm{~cm}$ from its edge (MacDiarmid and Watkin, 1971; Borghesio et al., 1999). Plant species differ in their relative uptake-rate of dung $\mathrm{N}$. Jørgensen and Jensen (1997) found that mineralised dung $\mathrm{N}$ was primarily taken up by grass in grass-legume mixtures. The increased plant growth and differential dung $\mathrm{N}$-uptake, combined with cattle avoidance of pat surroundings is likely to influence plant species assemblages (Marsh and Campling, 1970). Furthermore, many authors showed the importance of dung for seed dispersal, germination and soil seed bank composition, which may also induce changes in vegetation composition (Welch, 1985; Akbar et al., 1995; Malo and Suarez, 1995; Dai, 2000; Bakker and Olff, 2003). Indeed Dai (1998) showed that the patch size of some plant species in alvar limestone grassland were similar to the average size of cattle dung pats, suggesting a correlation between species development and dung pats. However, studies on the effect of dung deposition on vegetation dynamics at a very fine spatial and temporal scale have not been documented so far.

The aim of our observational study was to investigate the time course and outcome of vegetation response to dung deposition involving complex interactions in space and time among various fine-scale ecosystem processes, such as nutrient release, immigration from seed input, plant growth, competition for light and herbage removal by cattle. This vegetation response was monitored in two typical plant community types of mountain pastures in order to detect changes in community texture (species composition and dominance, species richness and evenness) and structure (vegetation height, patch formation, species turnover) in space (distance to the centre of the dung pat) and time (time elapsed from the dunging event). We measured the spatial and temporal extent of the avoidance area around individual dung pats by considering vegetation height and grazing intensity. It was hypothesized that (1) dung deposition would induce a decreasing gradient of species richness (due to disturbance and immigration effects) and an increasing gradient of evenness (due to the competition effect following nutrient release and cattle avoidance) when one moves away from the dung pat; (2) changes in abiotic and biotic conditions would affect plant species composition so that species turnover would be stimulated in the vicinity of the dung pats; (3) the variation in species composition explained by the distance to the dung pat would be lower in the less productive community type, since preliminary personal observations have suggested that stress-tolerating grasslands on dry calcareous soils were less affected by fertilisation and grazing than other vegetation types.

\section{Materials and methods}

\subsection{Study site}

This study was conducted in the Jura Mountains of northwestern Switzerland. The study site is located in La Métairie d'Évilard (Orvin BE, $47^{\circ} 09^{\prime} \mathrm{N}, 7^{\circ} 10^{\prime} \mathrm{W}$ ) at an altitude of about $1200 \mathrm{~m}$ a.s.l. The climate is predominantly temperate oceanic, with mean annual rainfall of about $1600 \mathrm{~mm}$ (including more than $400 \mathrm{~mm}$ snow precipitation) and mean annual temperature of $7^{\circ} \mathrm{C}$. The ground is covered with snow from November to April. The area contains a great diversity of habitats, from open grassland to forest patches, with flat or sloping ground on a heterogeneous soil mosaic (Leptosols, Cambisols, Luvisols; taxonomy after Deckers et al., 1998). This landscape is the result of a long history of silvopastoral management. The current management is extensive (relatively low stocking rate and low fertilization) with a rotational grazing system. During the observation period from June to September 2001, 120 heifers (49.2 Adult Bovine Units, 29,520 kg live-weight) stayed three times (rotations) in the two paddocks of about 25 ha each. Each rotation lasted approximately 15 days. The herd was a mix of Holstein and Swiss brown breeds.

\subsection{Sampling design and measurements}

Two typical and well represented plant communities, composed almost completely of perennial species building the mosaic of the herb layer, were chosen in two different paddocks. In the first paddock, the plant community appears widespread in open flat areas on soils of about $20 \mathrm{~cm}$ depth, developed on a mixed loesslimestone substrate, with a $\mathrm{pH}$ close to 5 . This relatively productive community was a grazed mesotrophic grassland (MG in this paper) dominated by Festuca nigrescens, Ranunculus acris ssp. friesianus and Trifolium repens (nomenclature follows Tutin et al. (19641980)). In the second paddock, the plant community also occurs in open flat areas but on shallow and nutrient-poor calcareous soils of about $5 \mathrm{~cm}$ depth and with a $\mathrm{pH}$ around 6.5. This grazed oligotrophic limestone grassland (OG in this paper) was dominated by Sanguisorba minor, Plantago media and Plantago lanceolata.

In each plant community, we randomly selected 10 fresh dung pats one week after cattle came into the paddock for the first time of the year. Because the two vegetation types were not in the same paddock and cattle not in both paddocks at the same time, the dung pats in MG were selected at the beginning of June and those in OG at the beginning of July. The selected dung pats were recorded four times in MG (1, 5, 9 and 14 weeks after dung deposition) and three times in OG (1, 7 and 12 weeks after dung deposition). Only five dung pats in MG and six in OG could be monitored throughout the full season. The other pats were lost due to cattle trampling or because new dung pats were dropped on or very close to the monitored dung pats. 
To monitor the vegetation at a spatial resolution of $0.01 \mathrm{~m}^{2}$, we used a cross-shaped frame with four arms of 6 square cells each and a cluster of 9 cells in the centre (Fig. 1). The 33-cell frame was centred on the dung pat before the first observation period with a random orientation of the arms. The device, once oriented for the first time, was re-installed in exactly the same place in the consecutive field sessions thanks to permanent plastic tubes sunk $2 \mathrm{~cm}$ below ground level to avoid any interference with cattle behaviour. Because of the highly dense vegetation, the frame was installed just before each observation period at $0.15 \mathrm{~m}$ above the ground.

The relative area occupied by the dung pat (dung cover) was estimated inside each central cell of the frame. We recorded in each cell and at every observation period the exhaustive list of species present and estimated for each species the absolute cover with Braun-Blanquet's dominance code (from 1 to 5 ) and the maximum height of vegetative parts with a 5-cm class index. Additionally, we noted for every species in every cell if it was grazed or not. This rough binary index appeared to be a good compromise between precision and efficiency. All observations were made carefully by the same observer so that we can assume that observer impact was the same for all observations across space and time.

It was impossible to describe initial vegetation of experimental plots before the treatment because the location for dung deposition was unpredictable. However, it is very unlikely that the patterns observed across the four arms around several dung pats would be due to a common structure occurring prior to dung deposition. Moreover, terminal cells at $50-60 \mathrm{~cm}$ from the dung pat can be considered as control since vegetation is not likely to be influenced by this dung at such distance.

To allow comparison between observation periods, only dung pats recorded throughout the full season were retained for the analyses. This resulted for MG in 5 dung pats $\times 4$ observation periods $\times 33$ cells $=660$ cell records, and for OG in 6 dung pats $\times 3$ observation periods $\times 33$ cells $=594$ cell records.

\subsection{Data transformations}

The semi-quantitative index of vegetation height was transformed into a quantitative variable by taking the median of each class (1: $2.5 \mathrm{~cm} ; 2: 7.5 \mathrm{~cm} ; 3: 12.5 \mathrm{~cm}$; and so on). We calculated

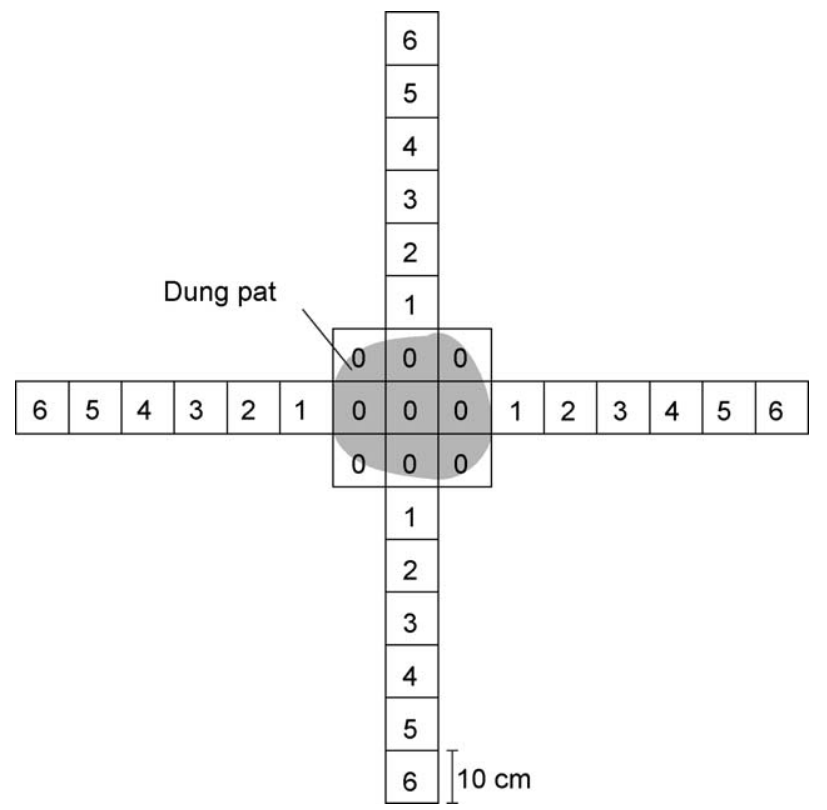

Fig. 1. Sketch of the cross-grid sampling frame. Cells in the grid were $10 \mathrm{~cm} \times 10 \mathrm{~cm}$. Numbers represent distance classes. for each observation period an average canopy height per cell, by weighting the height by the relative cover of the corresponding species.

The Braun-Blanquet's dominance codes recorded for each species were first transformed into median percentage cover ( 1 : 3\%; 2: $14 \%$; 3: $32 \%$; $4: 57 \%$ and 5: $90 \%$ ) to get proportional species dominances that could be summed or averaged among cells. We calculated for each cell at each observation period the ratio between the total percentage cover of the species that were noted as being grazed and the total cover of all species. This ratio was used as a surrogate of the grazing intensity.

We computed for each observation period in each cell the species richness and the species evenness, calculated as the Hill's ratio between inverse Simpson's diversity index $\mathrm{N}_{2}$ and species richness $\mathrm{N}_{0}$ (Hill, 1973; Peet, 1974; Gillet et al., 1999). The temporal species turnover between two successive observations in each cell was calculated by the Jaccard distance (1-Jaccard similarity) on presence-absence data.

For further analyses, we pooled the data by cell distances to the dung pats, resulting in seven distance classes: 0 : on the dung pat; $1: 0-10 \mathrm{~cm} ; 2: 10-20 \mathrm{~cm} ; 3: 20-30 \mathrm{~cm} ; 4: 30-40 \mathrm{~cm} ; 5: 40-50 \mathrm{~cm}$; 6: $50-60 \mathrm{~cm}$ (Fig. 1). We calculated for each dung pat and each response variable (species dominance, canopy height, grazing intensity, species richness, species evenness and species turnover) the average value of the 9 central cells, and for each distance class the average value over the four arms of the cross. Therefore, we obtained one value per distance class for each recorded dung pat, giving 7 different values per dung pat at each sampling date for every aggregated variable, which have been used in the following statistical analyses to test our hypotheses.

\subsection{Statistical analyses}

To measure the effect of the dung pat on the aggregated variables (hypotheses 1 and 2), we calculated for each observation period the Spearman's rank correlation coefficient between each variable (except species dominance used in the multivariate analyses) and the distance to the dung pat. For these correlations, the values calculated for the centre of the cross were omitted. These correlations were then computed from 30 records for MG ( 5 dung pats $\times 6$ distance classes) and from 36 records for OG ( 6 dung pats $\times 6$ distance classes). To account for differences among sampling units around dung pats due to the intrinsic variability and heterogeneity of the plant community, correlations were not directly done on raw data but on the residuals of a simple linear regression on dung pat label as a qualitative explanatory variable (considered as a block).

Partial redundancy analysis (RDA) was used to analyse for each observation period the multivariate species response to the distance to the dung pat, that is a single quantitative explanatory variable ranging from 1 to 6 (hypothesis 3). Hellinger transformation (Legendre and Gallagher, 2001) was applied to the response species matrix with aggregated dominance. As for Spearman's rank correlations, central cells were excluded and variation explained by sampling blocks was removed by using dung pat label as covariable. Since the multivariate response was constrained by a unique explanatory variable, the first axis was the only canonical axis and its eigenvalue was used to extract the variation explained by the distance to the dung (constrained variation) after accounting for the variation due to differences among blocks (conditioned variation). As the vector of the explanatory variable is positively correlated to the first axis $(r=1)$, species scores along this axis can be interpreted as their global response to the distance gradient. To test the significance of the RDA model, Monte Carlo permutation test was performed by permuting records freely within each block (999 permutations). 


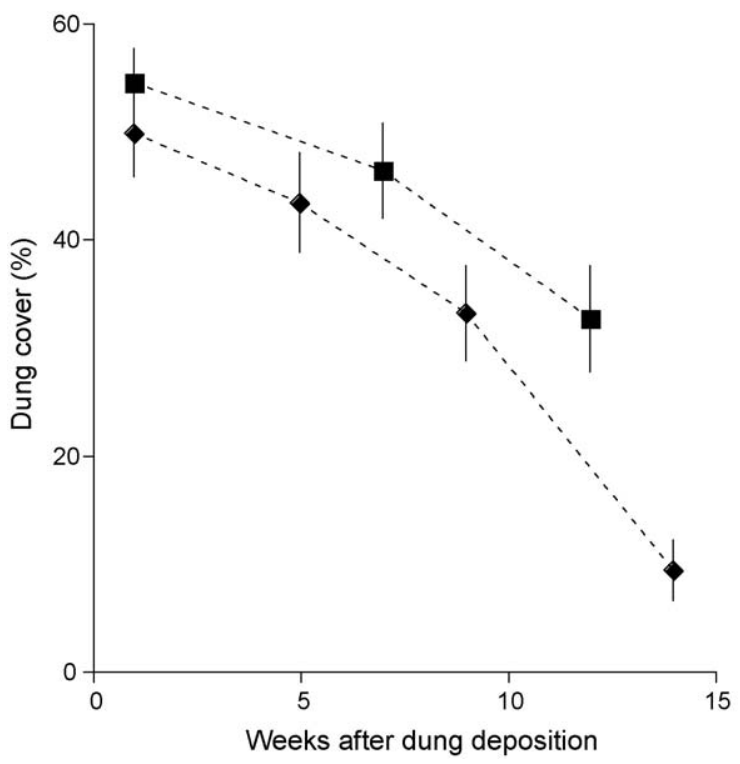

Fig. 2. Mean dung pat cover development in the 9 central cells. Segments represent standard error of the mean. Diamonds: MG; squares: OG.

All calculations and plots were performed with R 2.7.2 ( $R$ Development Core Team, 2008).

\section{Results}

\subsection{Changes in dung cover}

The dung pats occupied half of the 9 central cells at the first sampling date (Fig. 2). The dung cover decreased over time and this decrease was faster in MG where the dung had almost completely disappeared after 14 weeks.

\subsection{Canopy height and grazing intensity}

In MG, vegetation was already at the first observation higher near the dung pats (Table 1). The effect increased during the following months. In OG, we observed the same pattern except for the first observation. At final sampling, the tallest vegetation was found near the edge of the dung pat and vegetation size decreased linearly up to $50 \mathrm{~cm}$ distance in MG and up to $40 \mathrm{~cm}$ in OG where vegetation was lower (Fig. 3a). Further away vegetation height did not change anymore. The maximum difference in mean vegetation height was about $3.5 \mathrm{~cm}$ in MG and about $1 \mathrm{~cm}$ in OG.

There was a significant positive correlation between grazing intensity and distance for all sampling dates in both plant communities (Table 1): the further away from the dung pat, the more vegetation cover revealed traces of grazing. At the last observation grazing intensity showed a clear increase up to $50 \mathrm{~cm}$ away from the dung pat in MG (Fig. 3b). In OG, the transition was more abrupt at about $30 \mathrm{~cm}$ distance from the pat and the intensity of grazing was strongly lower than in MG.

\subsection{Species diversity and species turnover}

A total of 33 species were observed in MG and 38 in OG. The average number of species per cell was $7.1(S D=1.6$; $\max .=13)$ in MG and $9.8(\mathrm{SD}=2.1$; $\max .=16)$ in OG. Correlations between species richness, evenness or temporal turnover and the distance to the dung pat are presented in Tables 1 and 2. For the two first observations, there was a tendency in MG to harbour more species near the dung. The correlation was significant in OG at the first observation. This pattern disappeared during the season (Fig. 3c). For the evenness we found a negative correlation at the fourth sampling date in MG (Fig. 3d). There were no significant correlations in OG.

Vegetation dynamics were higher afar from the dung pat as all correlations were positive and significant for species turnover (Table 2). The turnover values between the first and the last observation along the distance gradient are presented in Fig. 3e. The pattern was similar in both plant communities. Turnover was high on the dung pat and lowest at a distance of $0-10 \mathrm{~cm}$. After this drop turnover increased further away in MG, and a similar but weaker trend appeared in OG.

\subsection{Compositional gradients around the dung pat}

The distance to the dung pat significantly explained the variation in the species assemblage data matrix from the second observation in MG (after 5 weeks) and OG (after 7 weeks) (Table 3). Explained variation was lower in OG and increased slowly over time. The position of each species along the first axis of the RDA for each significant observation period is presented in Fig. 4. Because we used only one explanatory variable in the RDA model, the species scores along the first axis represent the floristic gradient explained by the distance to the dung. For MG, we observed that for some species the position along the first axis changed over time. Nevertheless, some species showed a stable pattern throughout the season. F. nigrescens, Thymus pulegioides and Trifolium pratense were always more abundant far from the dung pat. In contrast, Rumex acetosa, Crepis mollis, T. repens and P. lanceolata were more abundant near the dung pat. In OG, T. pulegioides was also less abundant near the dung whereas $P$. lanceolata, $C$. mollis and $R$. acetosa became also more abundant after 12 weeks.

In MG, an average of 1.6 species $(S E=1.1 ; \max .=6 ; \min .=0)$, which were never observed in the four related arms ( 24 cells) during the season, appeared at least once in the 9 central cells. After grouping all central areas, only one species (Avenula pubescens) was found in these central areas but not around the dung pats (all arms together). In OG, an average of 1.2 species ( $\mathrm{SE}=0.4 ; \max =2$;

Table 1

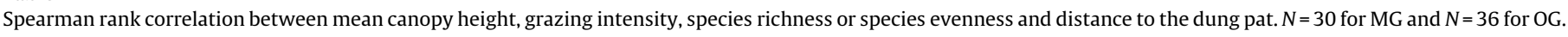

\begin{tabular}{|c|c|c|c|c|c|c|c|c|}
\hline & \multicolumn{2}{|c|}{ Canopy height } & \multicolumn{2}{|c|}{ Grazing intensity } & \multicolumn{2}{|c|}{ Species richness } & \multicolumn{2}{|c|}{ Species evenness } \\
\hline & MG & OG & MG & OG & MG & OG & MG & OG \\
\hline +1 week & $-0.474^{* *}$ & -0.027 & $0.371^{*}$ & $0.353^{*}$ & $-0.349^{\bullet}$ & $-0.556^{* * *}$ & -0.094 & -0.122 \\
\hline$+5-7$ weeks & $-0.432^{*}$ & $-0.692^{* * *}$ & $0.649^{* *}$ & $0.773^{* * *}$ & $-0.320^{\bullet}$ & -0.065 & -0.249 & -0.092 \\
\hline +9-12 weeks & $-0.441^{*}$ & $-0.730^{* * *}$ & $-^{a}$ & $0.822^{* * *}$ & -0.144 & 0.073 & $-0.351^{\bullet}$ & -0.238 \\
\hline +14 weeks & $-0.829^{* *}$ & - & $0.824^{* * *}$ & - & -0.085 & - & $-0.533^{* *}$ & - \\
\hline
\end{tabular}

a There were no cattle in the paddock between weeks 5 and 9 in MG.

${ }^{*} P<0.05$.

$P<0.01$

${ }^{* * *} P<0.001$.

$\bullet P<0.1$. 

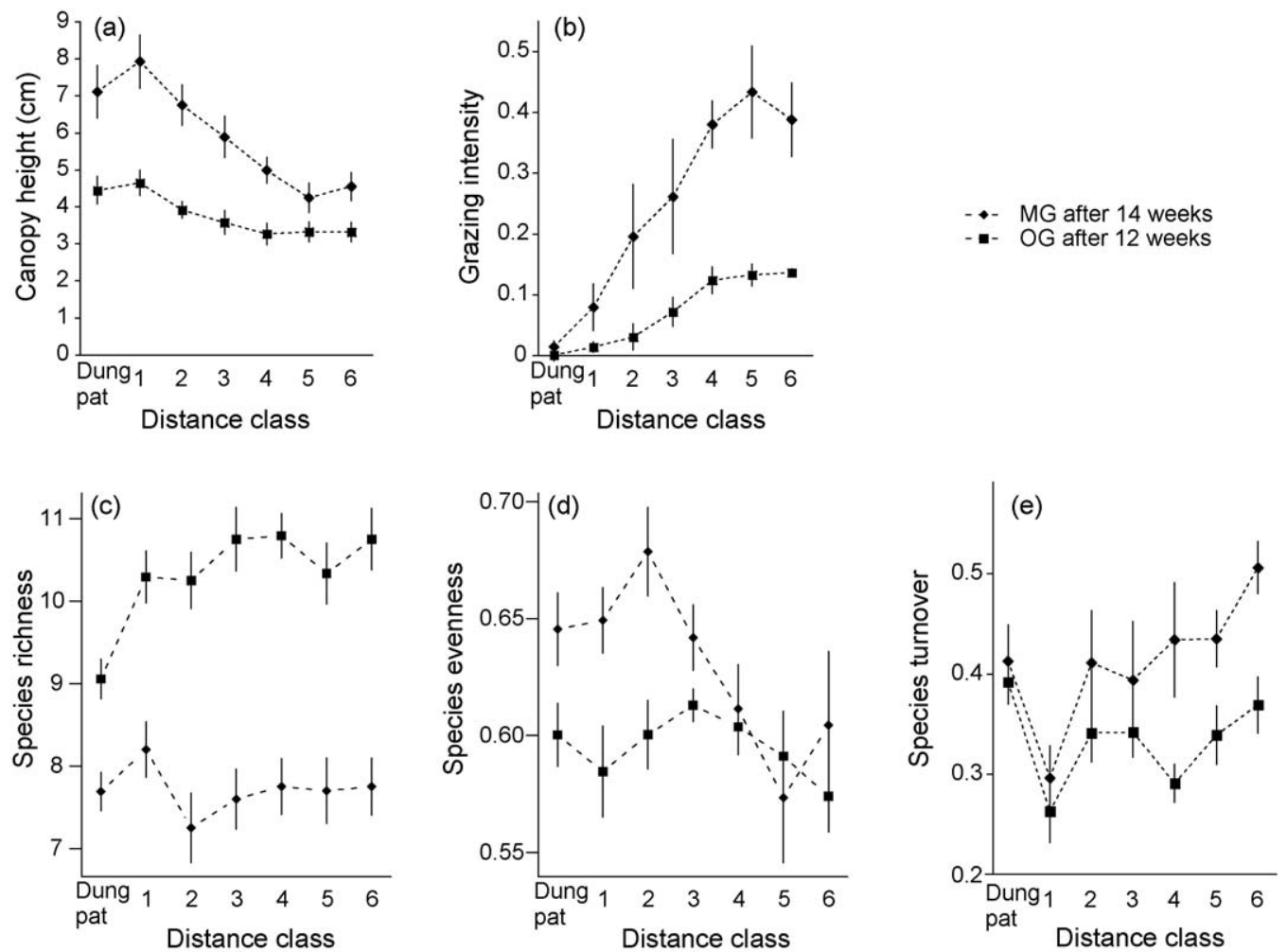

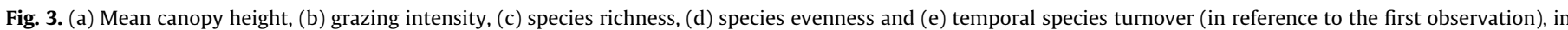

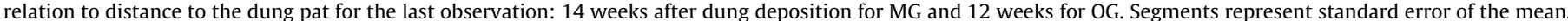
Diamonds: MG; squares: OG.

min. $=0$ ) were recorded in the central area but never in the related arms. When we compared all central areas together with all records made in the arms, only one species ( $T$. repens) was recorded only on or in the direct vicinity of the dung pat.

\section{Discussion}

Combining our results with previous studies, we can define four zones that are induced by the deposition of a dung pat: (1) the dung

Table 2

Spearman rank correlation between species turnover and the distance to the dung pat. $N=30$ for MG and $N=36$ for OG.

\begin{tabular}{lll}
\hline & \multicolumn{2}{l}{ Species turnover } \\
\cline { 2 - 3 } & MG & OG \\
\hline Between weeks 1 and 5-7 & $0.396^{*}$ & $0.424^{*}$ \\
Between weeks 5-7 and 9-12 & $0.369^{*}$ & $0.478^{* *}$ \\
Between weeks 9 and 14 & $0.427^{* *}$ & - \\
Between weeks 1 and 12-14 & $0.576^{* *}$ & $0.438^{* *}$ \\
\hline
\end{tabular}

${ }^{*} P<0.05$.

** $P<0.01$.

Table 3

Variation in species composition explained by the distance to the dung pat after partial RDA on the Hellinger-transformed species matrix. P: $P$-value of Monte Carlo permutation test with 999 permutations (permutations were restricted within each sampling block). Axis 1 of each significant observation is presented in Fig. 4.

\begin{tabular}{llllll}
\hline & MG & & & OG \\
\cline { 2 - 3 } \cline { 5 - 6 } & $\begin{array}{l}\text { Constrained } \\
\text { variation (\%) }\end{array}$ & $P$ & & $\begin{array}{l}\text { Constrained } \\
\text { variation (\%) }\end{array}$ & $P$ \\
\hline +1 week & 2.0 & 0.327 & & 2.5 & 0.138 \\
$+5-7$ weeks & 7.0 & 0.001 & & 2.7 & 0.031 \\
$+9-12$ weeks & 3.2 & 0.021 & & 3.2 & 0.016 \\
+14 weeks & 3.2 & 0.001 & & - & - \\
\hline
\end{tabular}

itself, which creates a gap after destroying the above-ground plant biomass, (2) the first $10 \mathrm{~cm}$ around the pat, where the vegetation is not grazed (Fig. 3) but fertilized (MacDiarmid and Watkin, 1972), (3) between 20 and $30 \mathrm{~cm}$, a zone with low grazing rates and probably low fertilization (Deenen and Middelkoop, 1992) and (4) beyond $40 \mathrm{~cm}$, a zone which is no longer influenced by the dung pat. In our study, the gradient of grazing intensity parallel to distance from the dung pat was already detected one week after deposition. Moreover, the increasing positive correlations during following observations (Table 1) were probably due to a cumulative grazing effect. The patterns of grazing intensity and vegetation height along the distance gradient were similar in both mesotrophic and oligotrophic limestone grassland type, although less perceptible in OG (Fig. 2). This indicates that our outcome depended on the dung pats and not on the vegetation texture or structure. Marsh and Campling (1970) suggested that the avoidance of herbage around the dung pat is related to the smell of the dung and thus independent of the vegetation type. The difference between both plant communities was the rapidity of reaction, which was slower in OG than in MG (Table 1). This was most likely due to a higher proportion of species of the oligotrophic habitat which are less efficient in responding quickly to increased nutrient availability (Chapin et al., 1986).

The vegetation around dung pats was indeed submitted to two opposite nutrient and grazing intensity gradients, which induced changes in the vegetation texture at fine scale and short term. We observed an elevated number of species near the dung pat as compared to further away at the first observation in both vegetation types and at the second observation in MG (Table 1). This effect disappeared during the season indicating a transient increase of species number. The combination of low vegetation height and density at the beginning of the season and the lack of grazing activity very close to the dung pat likely induced favourable conditions for many species to develop and thus a 
MG after 5 weeks

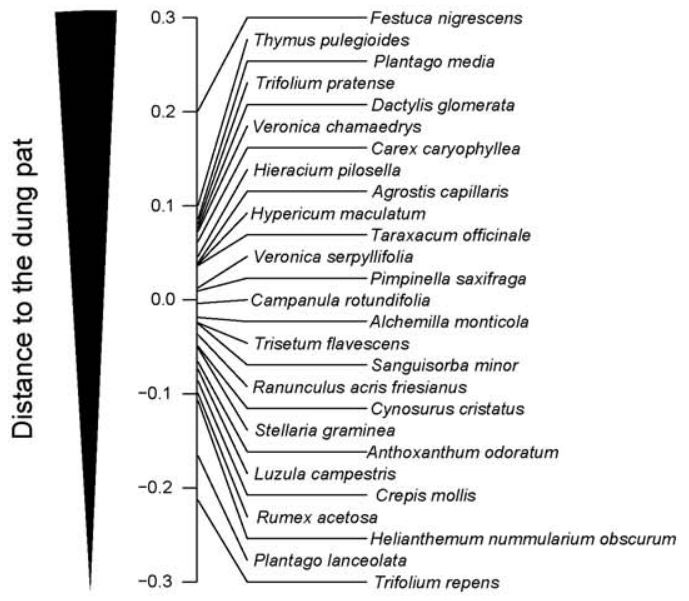

MG after 9 weeks

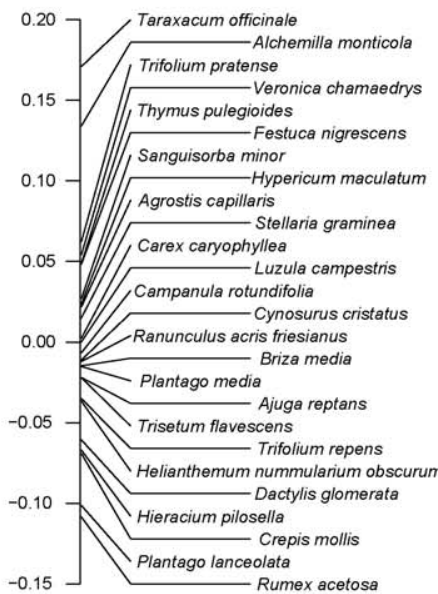

MG after 14 weeks

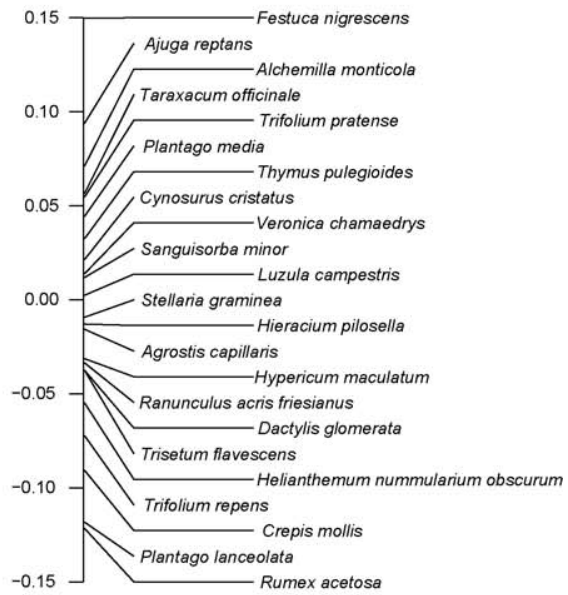

OG after 7 weeks

OG after 12 weeks
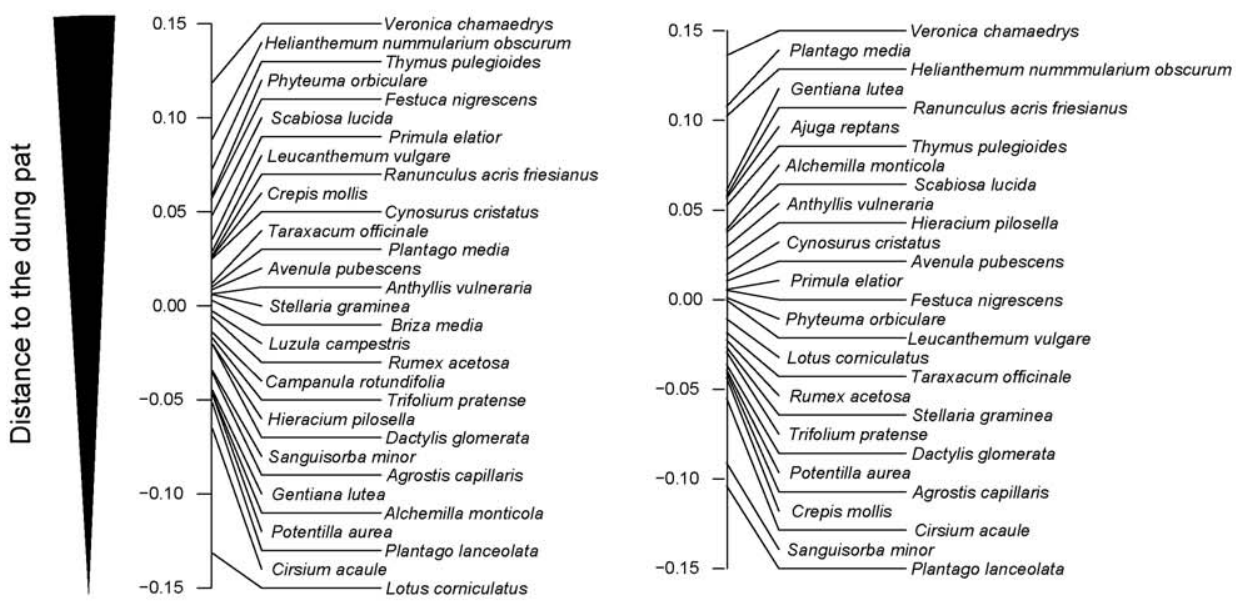

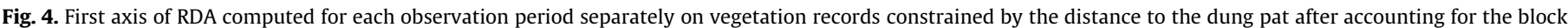

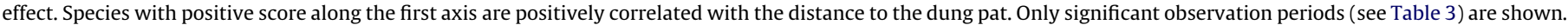

higher species richness. Some species were no longer able to survive when canopy height increased due to enhanced competition for light. Thus, the slightly higher diversity near the dung will likely only last for a short period. In MG, the evenness was higher near the dung pat at the third and fourth observations (Fig. 3d). This surprising result indicates that higher nutrient supply and grazing abandonment did not, on the seasonal scale, favour exclusively a few dominating species, contrary to our first hypothesis.

Contrary to our expectations (hypothesis 2), the turnover rates were always significantly lower near the dung pat in both vegetation types (Table 2 and Fig. 3). On the dung pat we observed a high turnover which may be explained by recolonization of the gap after suppression of the above-ground biomass. However, the low turnover directly beside the dung suggests that dung pats have at short term a stabilising effect on plant composition of their direct surroundings $(0-10 \mathrm{~cm})$. The disappearance of the grazing disturbance in this area might explain this observation. The higher turnover further away from the dung pats at this small scale is a characteristic feature of grasslands (Van der Maarel and Sykes, 1993; Otsus and Zobel, 2002). Moreover, as reported for the same communities by Kohler et al. (2004b), OG had an overall lower turnover than MG. This could be due to the fact that the vegetation in OG grows under low soil nutrient availability and in relatively dry conditions leading to a lower growth rate.

In accordance with our hypothesis 3, floristic composition varied significantly along the distance gradient from the second observation period in both communities but the variation explained was lower in the less productive community OG (Table 3 and Fig. 4). The constrained variation explained by distance (ranging from 2.0 to $7.0 \%$ ) was however very low as compared to the conditioned variation explained by the block effect (ranging from 44.8 to $68.2 \%$ ), meaning that other factors that were not included in the model could better explain the variation in the data matrix. Nevertheless, our aim was to measure the impact of dung deposition and not to describe all factors influencing vegetation composition at this fine scale. In MG, after 14 weeks, tall forb and grass species characteristic of eutrophic mown meadows (R. acetosa, C. mollis, Trisetum flavescens), which are strong competitors, were more abundant near the dung pat. Further away from the dung, short forb species indicating oligotrophic conditions such as $T$. pulegioides or $P$. media, which are weak competitors, were found together with the regular dominant species of the community F. nigrescens and Alchemilla monticola. Close to the dung pat, the fertilizing effect of dung decomposition combined with grazing avoidance favours 
competitive strategists (nutrient demanding tall species) against stress-tolerant or perturbation-resistant strategists (Grime, 2001). In an experimental study carried out by Kohler et al. (2004a) at the same time scale similar effects were observed on plots fertilized or mowed twice a month. This species segregation was less clear in OG, probably because of the slower dynamics of this community. This finding could seem peculiar, since the fertilizing impact could be expected to be more pronounced in oligotrophic circumstances. However, this expectation is probably true for acidophilous grasslands, which are very sensitive to fertilisation (personal observations), but apparently not for dry calcareous grasslands.

Dai (2000) recognized three types of species response to dung deposition in a long-term experiment: negative, positive and neutral depending on the difference in cover along a transect across dung pats. He described changes in relative abundance of species but no establishment of typical vegetation linked to dung pats. Our observations confirmed this finding. Only very few new species appeared and the few new species recorded were common species of the studied pastures. Moreover, the observed disappearance and appearance of some species between successive observations can easily be explained by vegetative phenology and local disturbances. Indeed, the seasonal species turnover observed far from the dung is also partly due to vegetative phenology (Kohler et al., 2004b). We cannot exclude that the observer missed some species at the beginning or the end of their vegetative development. But the fact that species turnover is lower close to the dung shows that the stabilizing effect is independent on seasonality.

\section{Conclusion}

At landscape scale, cattle have favoured dunging areas, associated with ruminating activity (Gander et al., 2003; Kohler et al., 2006). If landscape structures and cattle stocking rate do not change, the spatial pattern of dung deposition could remain constant over many decades (Jewell et al., 2007; Gillet, 2008). At this scale, in areas with high dung pat density, plant species which react positively to high nutrient soil content will be more abundant and this pattern may be relatively stable over time. In contrast, at very fine scale, dung pats are dropped every year in different locations. These spatial changes create a shifting mosaic of nutrient availability and grazing intensity. As suggested by our observations, plant communities react rapidly to these changes and microsuccessions may be induced at seasonal scale, especially in mesotrophic pastures which appear as more susceptible to compositional changes. These micro-successions are likely to be temporary and cyclic phenomena affecting vegetation in pasture ecosystems at fine scale, but could become directional and propagate to larger scales in certain circumstances, such as change in local grazing pressure. Therefore, dung deposition, together with other cattle activities such as selective grazing, could play an important role in grassland ecosystems by promoting species turnover and habitat diversity. This highlights the need for further investigations on the role of large domestic herbivores in explaining the high plant biodiversity of mountain pastures (Schläpfer et al., 1998) and in enhancing their resilience in the current context of rapid changes in land use and climate.

\section{Acknowledgements}

We acknowledge the support of the Swiss National Science Foundation (grant 31-64116.00 and NCCR Plant Survival). We are also grateful to Stéphanie Reust for the field work, Jean-Michel Gobat and two anonymous reviewers for their sound advices and Nicolas Küffer for editing support.

\section{References}

Aarons, S.R., O'Connor, C.R., Gourley, C.J.P., 2004. Dung decomposition in temperate dairy pastures. I. Changes in soil chemical properties. Aust. J. Soil Res. 42, 107114.

Akbar, G., Call, C.A., Wiedmeier, R.D., 1995. Cattle dung pat microenvironmental effects on germination and establishment of crested wheatgrass. Arid Soil Res. Rehab. 9, 409-422.

Bakker, E.S., Olff, H., 2003. Impact of different-sized herbivores on recruitment opportunities for subordinate herbs in grasslands. J. Veg. Sci. 14, 465-474.

Bakker, E.S., Olff, H., Boekhoff, M., Gleichman, J.M., Berendse, F., 2004. Impact of herbivores on nitrogen cycling: contrasting effects of small and large species. Oecologia 138, 91-101.

Borghesio, L., Luzzato, M., Palestrini, C., 1999. Interactions between dung, plant and the dung fauna in a heathland in northern Italy. Pedobiologia 43, 97-109.

Buttler, A., Kohler, F., Gillet, F., 2008. The Swiss mountain wooded pastures: patterns and processes. In: Rigueiro-Rodríguez, A., McAdam, J.H., Mosquera-Losada, M.R. (Eds.), Agroforestry in Europe-Current Status and Future Prospects. Springer. Adv. Agrofor. 6, 377-396.

Chapin III, F.S., Vitousek, P.M., Van Cleve, K., 1986. The nature of nutrient limitation in plant communities. Am. Nat. 127, 48-58.

Dai, X., 1998. Small scale spatial pattern of core species in a limestone grassland in the Great Alvar on the Baltic island Öland, Sweden. Folia Geobot. 33, 147-158

Dai, X., 2000. Impact of cattle dung deposition on the distribution pattern of plant species in an alvar limestone grassland. J. Veg. Sci. 11, 715-724.

Deckers, J.A., Nachtergaele, F.O., Spaargaren, O.C., 1998. World Reference Base for Soil Resources: Introduction. Publishing Company Acco, Leuven.

Deenen, P., Middelkoop, N., 1992. Effects of cattle dung and urine on nitrogen uptake and yield of perennial ryegrass. Neth. J. Agric. Sci. 40, 469-482.

Dickinson, C.H., Craig, G., 1990. Effects of water on the decomposition and release of nutrients from cow pats. New Phytol. 115, 139-147.

Edwards, P.J., Hollis, S., 1982. The distribution of excreta on new forest grassland used by cattle, ponies and deer. J. Appl. Ecol. 19, 953-964.

Gander, A., Rockmann, A., Strehler, C., Güsewell, S., 2003. Habitat use by Scottish Highland cattle in a lakeshore wetland. Br. Geobot. I. ETH 69, 3-13.

Gillet, F., 2008. Modelling vegetation dynamics in heterogeneous pasture-woodland landscapes. Ecol. Model. 217, 1-18.

Gillet, F., Murisier, B., Buttler, A., Gallandat, J.D., Gobat, J.M., 1999. Influence of tree cover on the diversity of herbaceous communities in subalpine wooded pastures. Appl. Veg. Sci. 2, 47-54.

Grime, J.P., 2001. Plant Strategies, Vegetation Processes, and Ecosystem Properties. Wiley, Chichester, UK.

Guretzky, J.A., Moore, K.J., Burras, C.L., Brummer, E.C., 2007. Plant species richness in relation to pasture position, management, and scale. Agric. Ecosyst. Environ. 122, 387-391.

Haynes, R.J., Williams, P.H., 1993. Nutrient cycling and soil fertility in the grazed pasture ecosystem. Adv. Agron. 49, 119-199.

Hill, M.O., 1973. Diversity and evenness: a unifying notation and its consequences. Ecology 54, 427-431.

Hutchings, M.R., Kyriazakis, I., Gordon, I.J., Jackson, F., 1999. Tradeoffs between nutrient intake and fecal avoidance in herbivore foraging decisions: the effect of animal parasite status level on feeding motivation and sward nitrogen content. J. Anim. Ecol. 68, 310-323.

Jaramillo, V.J., Detling, J.K., 1992. Small-scale grazing in a semi-arid north American grassland. II. Cattle grazing of simulated urine patches. J. Appl. Ecol. 29, 9-13.

Jewell, P.L., Güsewell, S., Berry, N.R., Käuferle, D., Kreuzer, M., Edwards, P.J., 2005. Vegetation patterns maintained by cattle grazing on a degraded mountain pasture. Bot. Helv. 115, 109-124.

Jewell, P.L., Käuferle, D., Güsewell, S., Berry, N.R., Kreuzer, M., Edwards, P.J., 2007. Redistribution of phosphorus by cattle on a traditional mountain pasture in the Alps. Agric. Ecosyst. Environ. 122, 377-386.

Jørgensen, F.V., Jensen, E.S., 1997. Short-term effects of a dung pat on $\mathrm{N}_{2}$ fixation and total N uptake in a perennial ryegrass/white clover mixture. Plant Soil 196, 133141.

Kohler, F., Gillet, F., Gobat, J.-M., Buttler, A., 2004a. Seasonal vegetation changes in mountain pastures due to simulated effects of cattle grazing. J. Veg. Sci. 15, 143150.

Kohler, F., Gillet, F., Progin, M.-A., Gobat, J.-M., Buttler, A., 2004b. Seasonal dynamics of plant species at fine scale in wooded pastures. Comm. Ecol. 5, 7-17.

Kohler, F., Gillet, F., Reust, S., Wagner, H.H., Gadallah, F., Gobat, J.-M., Buttler, A., 2006. Spatial and seasonal patterns of cattle habitat use in mountain wooded pasture. Landscape Ecol. 21, 281-295.

Legendre, P., Gallagher, E.D., 2001. Ecologically meaningful transformations for ordination of species data. Oecologia 129, 271-280.

MacDiarmid, B.N., Watkin, B.R., 1971. The cattle dung patch. 1. Effect of dung patches on yield and botanical composition of surrounding and underlying pasture. J. Br. Grassland Soc. 26, 239-245.

MacDiarmid, B.N., Watkin, B.R., 1972. The cattle dung patch: 2. Effect of a dung patch on the chemical status of the soil, and ammonia nitrogen losses from the patch. 3. Distribution and rate of decay of dung patches and their influence on grazing behaviour. J. Br. Grassland Soc. 27, 43-54.

Malo, J.E., Suarez, F., 1995. Establishment of pasture species on cattle dung-the role of endozoochorous seeds. J. Veg. Sci. 6, 169-174.

Marsh, R., Campling, R.C., 1970. Fouling of pastures by dung. Herbage Abstr. 40, $123-130$. 
Moe, S.R., Wegge, P., 2008. Effects of deposition of deer dung on nutrient redistribution and on soil and plant nutrients on intensively grazed grasslands in lowland Nepal. Ecol. Res. 23, 227-234.

Olff, H., Ritchie, M.E., 1998. Effects of herbivores on grassland plant diversity. Trends Ecol. Evol. 13, 261-265.

Olff, H., Vera, F.W.M., Bokdam, J., Bakker, E.S., Gleichman, J.M., de Maeyer, K., Smit, R., 1999. Shifting mosaics in grazed woodlands driven by the alternation of plant facilitation and competition. Plant Biol. 1, 127-137.

Otsus, M., Zobel, M., 2002. Small-scale turnover in a calcareous grassland, its pattern and components. J. Veg. Sci. 13, 199-206.

Peet, R.K., 1974. The measurement of species diversity. Annu. Rev. Ecol. Syst. 5, 285 307.

R Development Core Team, 2008. R: A Language and Environment for Statistical Computing. R Foundation for Statistical Computing, Vienna, Austria. , http:// www.R-project.org.

Shepherd, M.J., Anderson, J.M., Bol, R., Allen, D.K., 2000. Incorporation of ${ }^{15} \mathrm{~N}$ from spiked cattle dung pats into soil under two moorland plant communities. Rapid Commun. Mass Spectrom. 14, 1361-1367.
Schläpfer, M., Zoller, H., Körner, C., 1998. Influences of mowing and grazing on plant species composition in calcareous grassland. Bot. Helv. 108, 57-67.

Steinauer, E.M., Collins, S.L., 2001. Feedback loops in ecological hierarchies following urine deposition in tallgrass prairie. Ecology 82, 1319-1329.

Tutin, T.G., Heywood, V.H., Burges, N.A., Valentine, D.H., Walters, S.M., Webb, D.A. 1964-1980. Flora Europaea. Band 1-5. Cambridge University Press, UK.

Van der Maarel, E., Sykes, M.T., 1993. Small-scale plant species turnover in a limestone grassland: the carousel model and some comments on the niche concept. J. Veg. Sci. 4, 179-188.

Weeda, W.C., 1967. The effect of cattle dung patches on pasture growth, botanical composition, and pasture utilisation. New Zeal. J. Agric. Res. 10, 150-159.

Welch, D., 1985. Studies in the grazing of heather moorland in north-east Scotland. J. Appl. Ecol. 22, 461-472.

Williams, P.H., Haynes, R.J., 1995. Effect of sheep, deer and cattle dung on herbage production and soil nutrient content. Grass Forage Sci. 50, 263-271.

White, S.L., Sheffield, R.E., Washburn, S.P., King, L.D., Green, J.T., 2001. Spatial and time distribution of dairy cattle excreta in an intensive pasture system. J. Environ. Qual. 30, 2180-2187. 